\title{
Compilation of liquefaction and pyrolysis method used for bio-oil production from various biomass: A review
}

\author{
Syahirah Faraheen Kabir Ahmad ${ }^{\dagger}$, Umi Fazara Md Ali, Khairuddin Md Isa \\ School of Environmental Engineering, University Malaysia Perlis, Kompleks Pusat Pengajian Jejawi 3, Perlis 02600, Malaysia
}

\begin{abstract}
In this paper the authors provide comparative evaluation of current research that used liquefaction and pyrolysis method for bio-oil production from various types of biomass. This paper review the resources of biomass, composition of biomass, properties of bio-oil from various biomass and also the utilizations of bio-oil in industry. The primary objective of this review article is to gather all recent data about production of bio-oil by using liquefaction and pyrolysis method and their yield and properties from different types of biomass from previous research. Shortage of fossil fuels as well as environmental concern has encouraged governments to focus on renewable energy resources. Biomass is regarded as an alternative to replace fossil fuels. There are several thermo-chemical conversion processes used to transform biomass into useful products, however in this review article the focus has been made on liquefaction and pyrolysis method because the liquid obtained which is known as bio-oil is the main interest in this review article. Bio-oil contains hundreds of chemical compound mainly phenol groups which make it suitable to be used as a replacement for fossil fuels.
\end{abstract}

Keywords: Biomass, Bio-oil, Liquefaction, Pyrolysis

\section{Introduction}

The search for cleaner energy sources is expanding each day due to the increasing of population and urbanization. Major energy resources such as petroleum, coal and natural gas might be depleted in the future. Global Energy Statistic reported that the overall energy demand is predicted to increase by $50 \%$ compare to energy demands reported in 2015. Besides that, burning of this energy sources can cause atmospheric pollution like global warming, acid rain and air pollution. With growing concerns for fossil fuel depletion and environmental threat, there is a strong interest in exploring renewable materials such as sunlight, wind, water and biomass as alternative feedstock for energy sources.

Biomass is readily available and renewable; it does not contain nitrogen and sulfur and does not affect the overall $\mathrm{CO}_{2}$ concentration in the atmosphere. Hence biomass is considered to be a good source of energy.

\section{Biomass}

\subsection{Definition}

Biomass is an organic material originated from plants, animals, and microorganisms which is non-fossilized and biodegradable. Biomass also comes in the form of products, byproducts, residues and waste from agriculture, forestry and related industries as well as the non-fossilized and biodegradable organic fractions of industrial and municipal solid wastes. Gases and liquids recovered from the decomposition of non-fossilized and biodegradable organic material also can be considered as biomass [1].

\subsection{Resources}

Biomass exists in two forms, woody and non woody. The woody biomass originates from plants while non-woody form originates from excess waste of animals, industry and crops. Biomass feedstock can be used in the form of liquid fuels, heat, electric power, and bio-based products. Fig. 1 shows most common biomass feedstock [2].
This is an Open Access article distributed under the terms of the Creative Commons Attribution Non-Commercial License (http://creativecommons.org/licenses/by-nc/3.0/) which permits unrestricted non-commercial use, distribution, and reproduction in any medium, provided the original work is properly cited.

Copyright (C) 2020 Korean Society of Environmental Engineers
Received December 2, 2018 Accepted February 18, 2019

${ }^{\dagger}$ Corresponding author

Email: faraheen.gemini@gmail.com

Tel: +60-1112508954 Fax: +60-49285067

ORCID: 0000-0002-5252-3407 


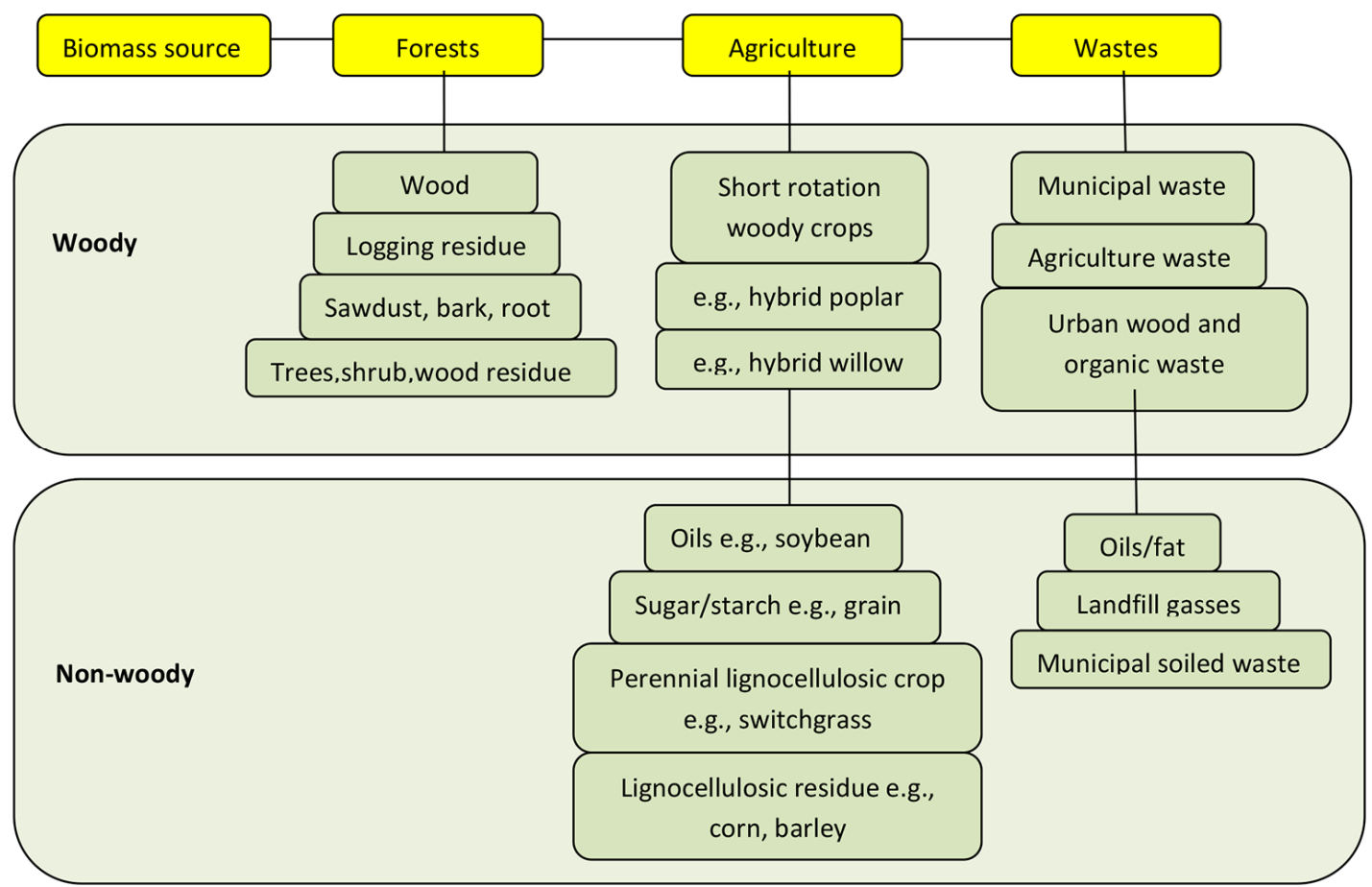

Fig. 1. Sources and types of biomass [2].

\subsection{Biomass Resource in Asian and European Countries}

Biomass is a renewable resource that is used to replace petroleum for the production of steam, heat and electricity. There are several Asian and European countries that have been using biomass as a source of energy such as United Kingdom, Spain, China, Kenya, Finland, Brazil, Sweden, Malaysia, Thailand, Pakistan and India. Biomass that is used in these countries is tabulated in Table 1.

Table 1. Biomass Used in Asian and European Countries

\begin{tabular}{llc}
\hline Country & \multicolumn{1}{c}{ Biomass resource } & References \\
\hline United & Arable crops: & \\
Kingdom & - Wheat \\
& - Barley \\
& - Oats \\
& - Rye, mixed corn and triticale \\
& - Oilseed rape \\
& - Linseed \\
& - Potatoes \\
& - Sugar beet \\
& - Peas \\
& - Maize \\
& \\
Horticultural crops: & - Grown outdoors vegetable \\
& - Orchard fruit \\
& - Soft fruit and wine grapes \\
& - Outdoor plants and flowers \\
& - Glasshouse crops
\end{tabular}

\begin{tabular}{|c|c|c|}
\hline Country & Biomass resource & References \\
\hline \multirow[t]{3}{*}{ Spain } & $\begin{array}{l}\text { Forest residue } \\
\text { - Waste from the treatment and use } \\
\text { of forest strand } \\
\text { - Wood agricultural residue } \\
\text { - Olives } \\
\text { - Vineyards and fruit trees }\end{array}$ & {$[4]$} \\
\hline & $\begin{array}{l}\text { Herbaceous residue } \\
\text { - Cereal straw } \\
\text { - Corn cane }\end{array}$ & \\
\hline & $\begin{array}{l}\text { Energy crops } \\
\text { - Rapeseed } \\
\text { - Sorghum } \\
\text { - Ethiopian thistle }\end{array}$ & \\
\hline China & $\begin{array}{l}\text { Rice, wheat, maize, beans, yam, cotton, } \\
\text { oilseed crops, sugar crops }\end{array}$ & {$[5,6]$} \\
\hline Kenya & $\begin{array}{l}\text { Charcoal, wood fuel and agriculture } \\
\text { waste }\end{array}$ & [7] \\
\hline Finland & Woody plant & [8] \\
\hline Brazil & $\begin{array}{l}\text { Sugar and alcohol sector } \\
\text { Paper and cellulose sector } \\
\text { Agricultural residue } \\
\text { Wood industry residue } \\
\text { Oleaginous plants }\end{array}$ & [9] \\
\hline
\end{tabular}




\begin{tabular}{|c|c|c|}
\hline Country & Biomass resource & References \\
\hline Sweden & $\begin{array}{l}\text { Forest industry: pulp, paper mills and } \\
\text { sawmills }\end{array}$ & [10] \\
\hline Malaysia & $\begin{array}{l}\text { Shell, fiber, empty fruit brunch. } \\
\text { Rice husks, rice straw } \\
\text { Logging residue, plywood, sawmill }\end{array}$ & {$[11,12]$} \\
\hline Thailand & $\begin{array}{l}\text { Bamboo biomass, woodchip, rice } \\
\text { husks }\end{array}$ & {$[13,14]$} \\
\hline Pakistan & Animal dung & [15] \\
\hline India & $\begin{array}{l}\text { Rice husk, waste wood, agricultural } \\
\text { residue }\end{array}$ & {$[16,17]$} \\
\hline
\end{tabular}

\subsection{Composition of Various Biomass}

Lignocellulosic biomass has varying amounts of cellulose, hemi-cellulose and lignin [18]. Hemicelluloses are a polymer constituted of sugar units. Cellulose is a glucose polymer which contain (1, 4)-D-glucopyranose units link with 1-4 in the $\beta$-configuration. Hemicellulose is different from cellulose, as it consist of primarily xylose and other five-carbon monosaccharides[19]. Lignin consists of cross linked, three-dimensional polymer formed with phenylpropane units. Generally, lignocellulosic biomass consist of $10-25 \%$ lignin, $20-30 \%$ hemicelluloses, and $40-50 \%$ cellulose [20]. The total amount of every component in lignocellulosic biomass is important to determine how effective the biomass can be converted into green fuels or valuable chemicals [21]. The weight percent of cellulose, hemicelluloses, and lignin varies depending on the type of biomass. Table 2 shows the compilations of lignocellulosic contents in different type of biomass.

\subsection{Elemental Composition and Physical Properties of Various Biomass}

Analysis of fuel is represented by the elemental composition (C, $\mathrm{H}, \mathrm{O}, \mathrm{N}$ and S), ash content, moisture content and higher heating value (HHV). The elemental composition of biomass is analyzed to evaluate the capability of the biomass to produce high value of bio-oil. The elemental analysis and physical properties of biomass is tabulated in Table 3. Table 3 illustrates the analysis of 11 types of lignocellulosic biomass.

Table 2. Chemical Compositions of Various Feedstock's for Bio-oil Production

\begin{tabular}{|c|c|c|c|c|}
\hline Biomass & Cellulose (wt\%) & Hemicellulose (wt\%) & Lignin (wt\%) & References \\
\hline EFB & 59.7 & 22.1 & 18.1 & {$[22]$} \\
\hline Sugarcane bagasse & 31.0 & 23.3 & 21.8 & {$[23]$} \\
\hline Rice husk & 31.3 & 24.3 & 14.3 & {$[24]$} \\
\hline Coconut shell & 34.0 & 21.0 & 27.0 & {$[25]$} \\
\hline Wood sawdust & 41.0 & 19.0 & 23.0 & {$[26,27]$} \\
\hline Corn stover & 31.0 & 43.0 & 13.0 & {$[22]$} \\
\hline Wheat straw & 32.4 & 41.8 & 16.7 & {$[22]$} \\
\hline Municipal solid waste (paper waste) & 58.8 & 11.2 & 1.0 & {$[28]$} \\
\hline Banana stem & 63.9 & 65.2 & 18.6 & {$[29]$} \\
\hline Softwood & $42 \pm 2$ & $27 \pm 2$ & $28 \pm 3$ & [19] \\
\hline Hardwood & $45 \pm 2$ & $30 \pm 5$ & $20 \pm 4$ & [19] \\
\hline
\end{tabular}

Table 3. Elemental Analysis and Physical Properties of Various Biomass

\begin{tabular}{lccccccccc}
\hline Biomass & $\mathbf{C}(\mathbf{w t} \%)$ & $\mathbf{H}(\mathbf{w t} \%)$ & $\mathbf{O}(\mathbf{w t} \%)$ & $\mathbf{N}$ (wt\%) & $\mathbf{S}$ (wt\%) & ash & moisture & HHV & Reference \\
\hline EFB & 51.78 & 7.04 & 40.31 & 0.72 & 0.16 & 4.64 & 7.38 & 18.74 & {$[30]$} \\
\hline Sugarcane bagasse & 58.14 & 6.05 & 34.57 & 0.69 & 0.19 & 4.34 & 16.07 & 18.61 & {$[31]$} \\
\hline Rice husk & 45.28 & 5.51 & 45.1 & 0.67 & 0.29 & 11.70 & 6.37 & 15.29 & {$[24,32,33]$} \\
\hline Coconut shell & 63.45 & 6.73 & 28.27 & 0.43 & 0.17 & 3.38 & 11.26 & 22.83 & {$[31]$} \\
\hline Wood sawdust & 52.00 & 6.07 & 41.55 & 0.28 & - & 0.10 & - & 20.407 & {$[34]$} \\
\hline Corn stover & 46.60 & 4.99 & 40.05 & 0.79 & 0.22 & 4.88 & 7.66 & 18.3 & {$[35,36]$} \\
\hline Wheat straw & 47.3 & 6.8 & 37.7 & 0.8 & - & - & 4.1 & - & {$[37]$} \\
\hline $\begin{array}{l}\text { Municipal solid waste } \\
\text { (paper waste) }\end{array}$ & 39.71 & 7.14 & 53.15 & - & - & 6.03 & 6.51 & - & {$[38]$} \\
\hline Banana stem & 38.2 & 5.3 & 43.4 & 0.3 & 0.49 & $8.04 \pm 0.17$ & $10.89 \pm 0.2$ & $13.70 \pm 0.10$ & {$[39,40]$} \\
\hline Softwood (av.) & 52.1 & 6.1 & 41.0 & 0.2 & - & 1.7 & - & 20.0 & {$[41]$} \\
\hline Hardwood (av.) & 48.6 & 6.2 & 41.1 & 0.4 & - & 2.7 & - & 18.8
\end{tabular}




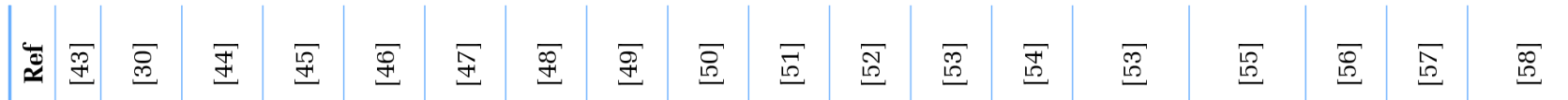

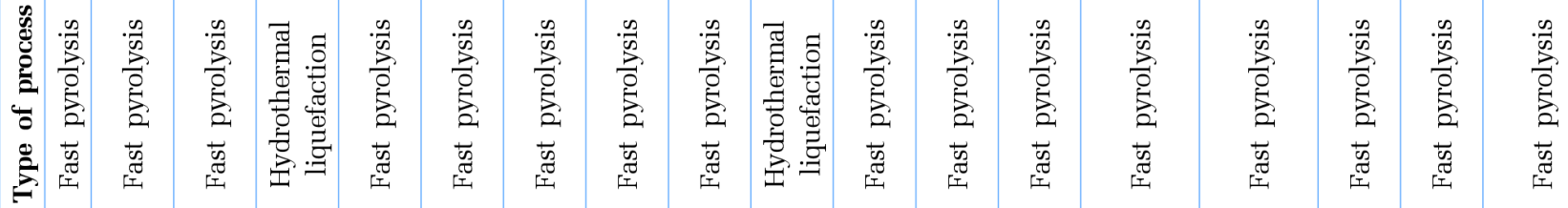

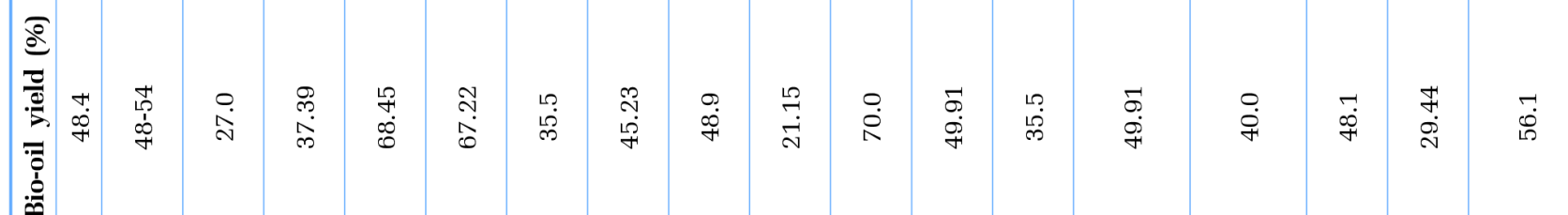

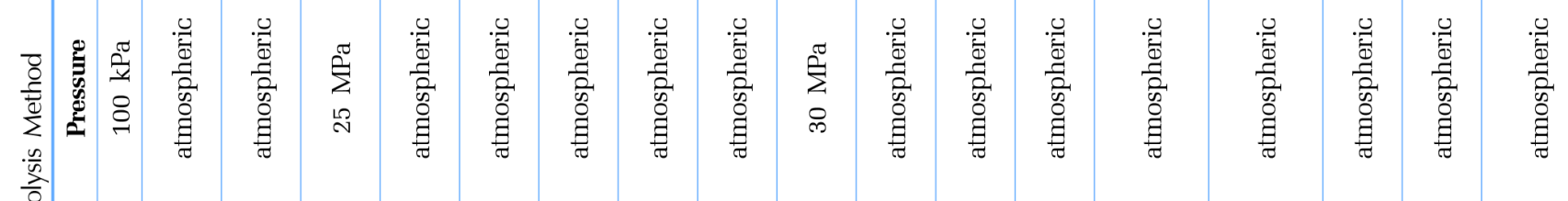
ì

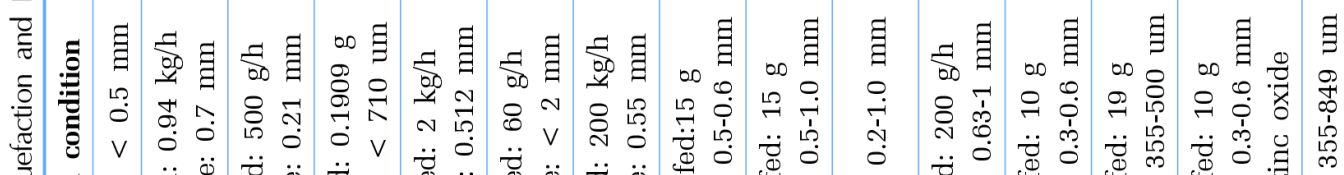

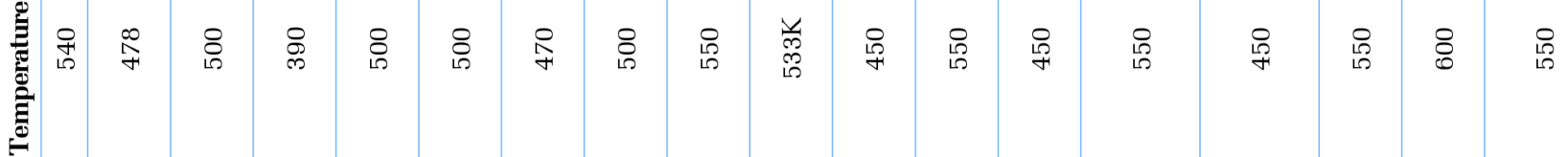

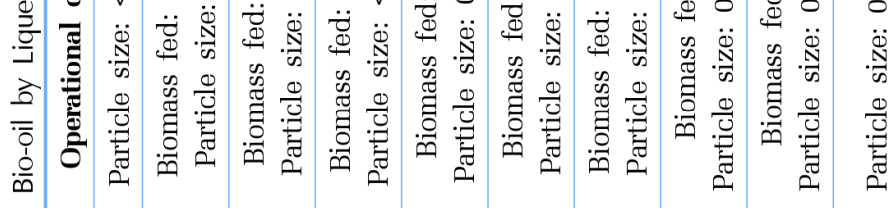

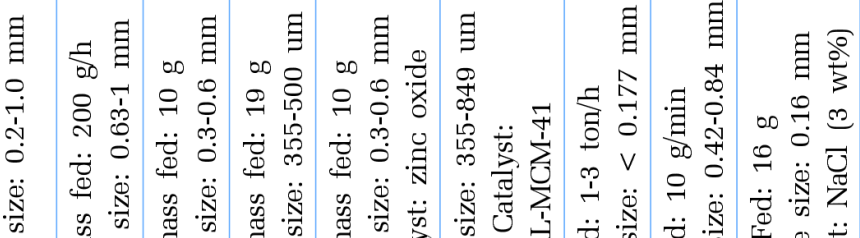

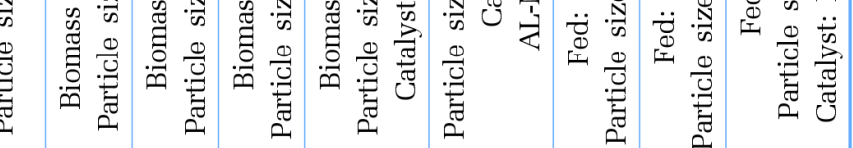

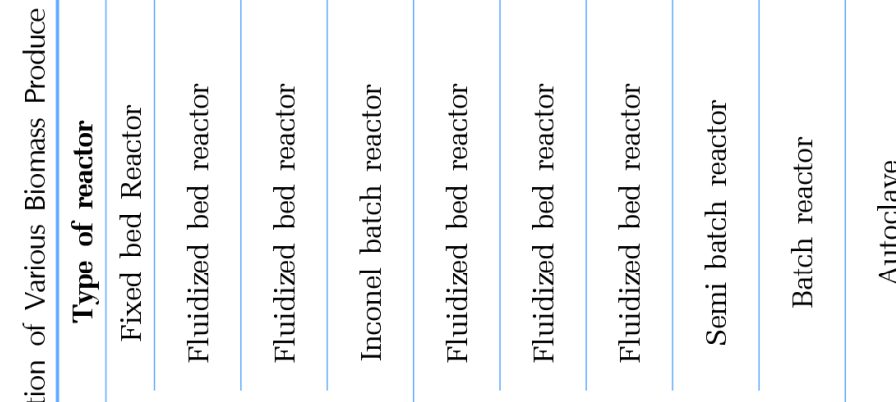

㱐
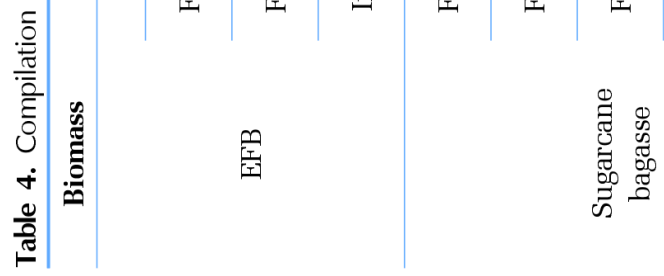

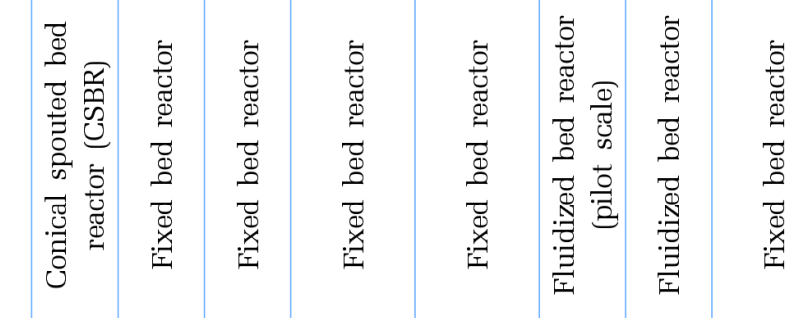




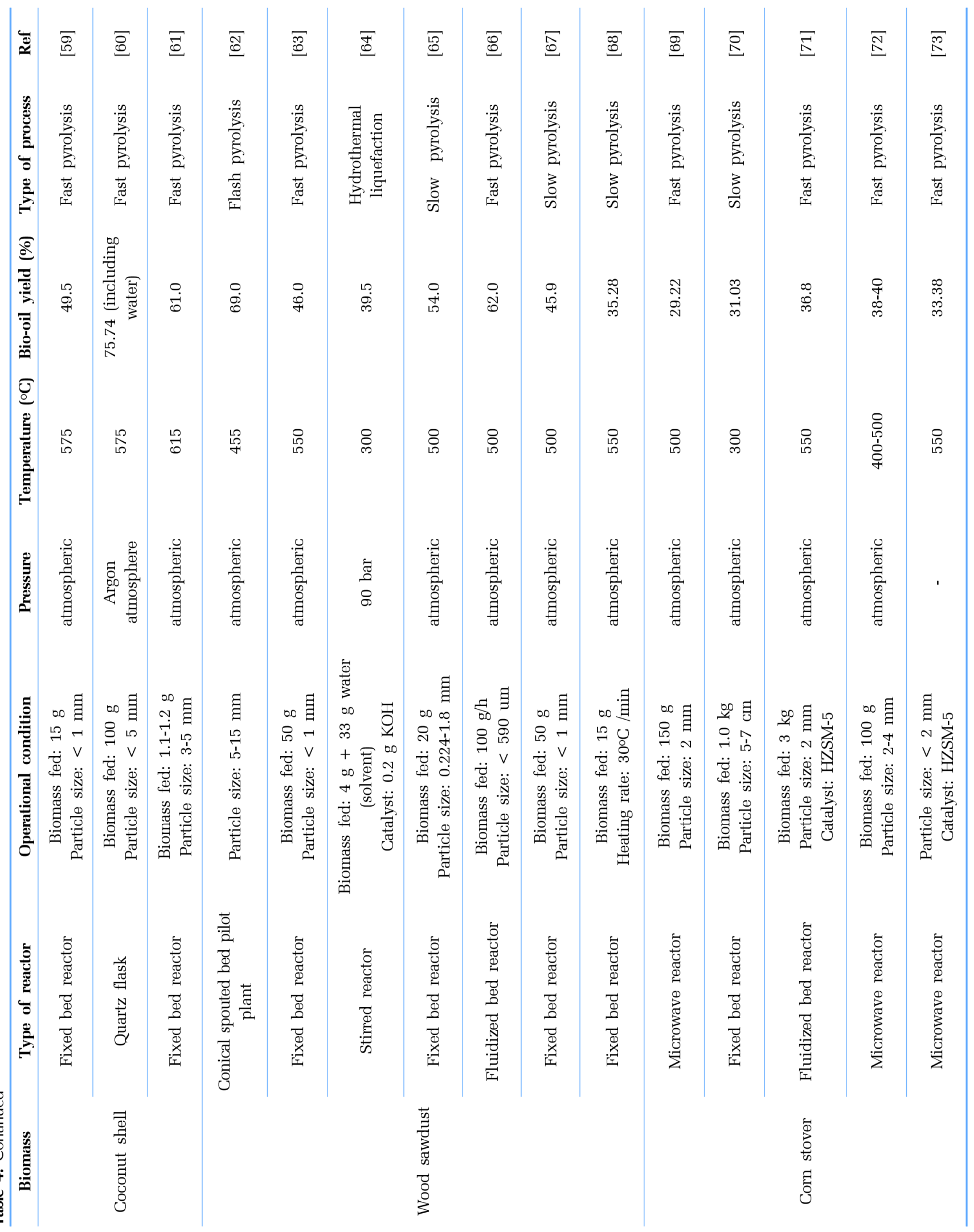




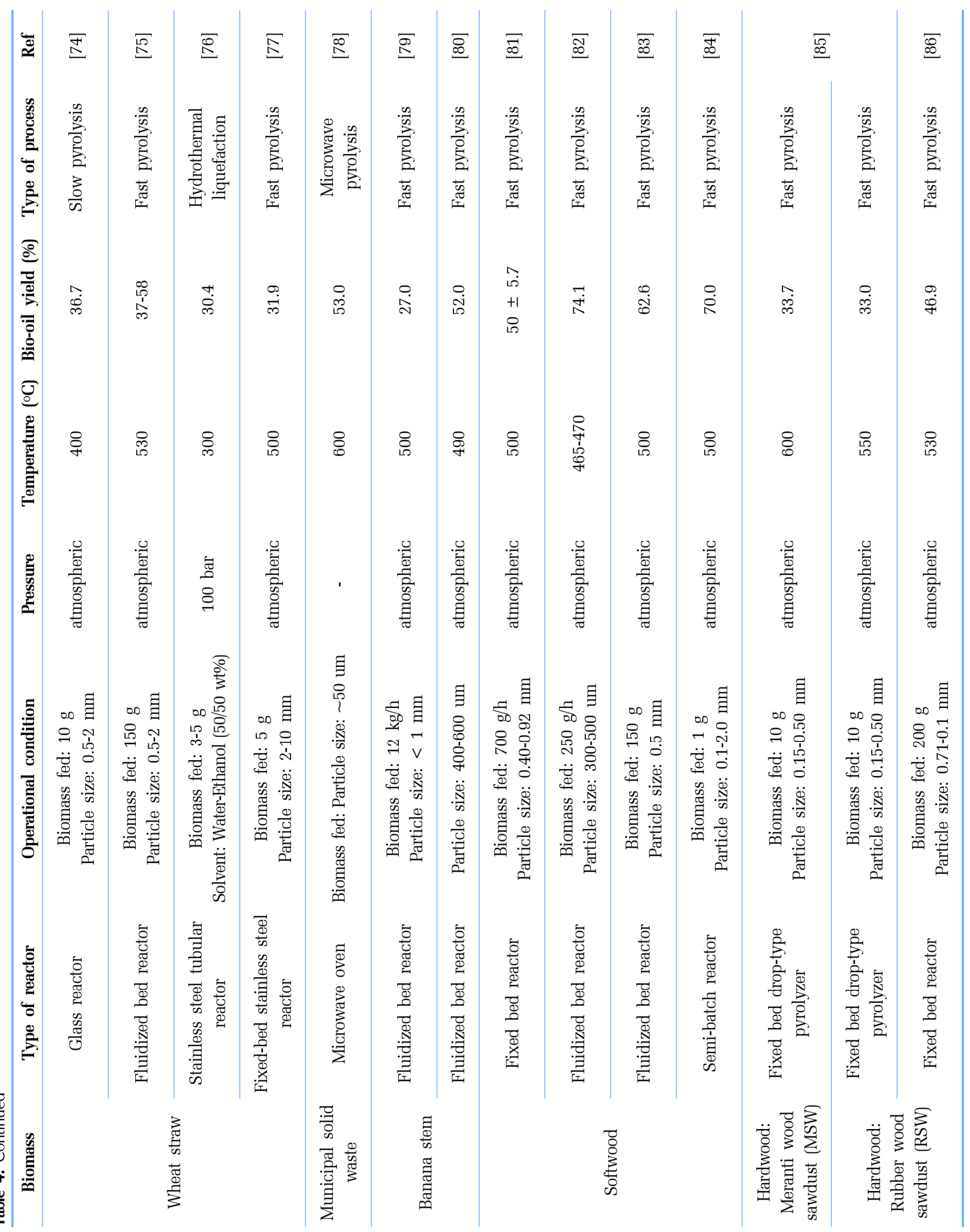




\subsection{Compilation of Various Biomass Produce Bio-oil by Liquefaction and Pyrolysis Method}

Table 4 represents the compilation of 11 types of lignocellulosic biomass used to produce bio-oil from recent research works which is $5 \mathrm{y}$ back (2013-2018). These compilations mainly focus on the production of bio-oil by using liquefaction and pyrolysis method with varied operational conditions. Table 4 lists all the parameters that have been investigated from previous research such as types of reactor and process, operational conditions, pressure, temperature, and yield. From the table it can be deduce that several types of process have been implemented by researchers, for instance hydrothermal liquefaction, microwave pyrolysis, and slow pyrolysis, but the most frequent process used are fast pyrolysis. Fast pyrolysis process is favorable as it can maximize the yield of bio-oil approximately about $80 \%$ based on dry feed and operational conditions used. Liquefaction process is less attractive among researchers compare to pyrolysis process as it produce lower yield of bio-oil (between 20-55 wt\%) and requires additional catalyst or other reactants to facilitate the process which is major drawback. Based on the compilation most of pyrolysis process takes place in a fixed bed reactor at atmospheric pressure within temperature range of $450^{\circ} \mathrm{C}$ to $600^{\circ} \mathrm{C}$. Fixed bed reactor is more effective compared to other reactor designs as it consist of ideal plug flow behavior, lower maintenance cost and reduce loss due to attrition and wear [42]. The highest yield of bio-oil is recorded from rice husk, coconut shell, and softwood which are at 70.0\%, 75.74\%, and $74.1 \%$.

\subsection{Properties of Bio-oil from Various Biomass}

Bio-oil is the product of depolymerization of biomass building blocks which are hemicelluloses, cellulose and lignin. Hence elemental composition of wood bio-oil is similar to biomass rather than petroleum oil. Table 5 shows comparison between properties of bio-oils from different feedstock. Water content in bio-oil comes from the original moisture in biomass and also from the product after pyrolysis process. High amounts of water content in bio-oil are considered as disadvantage for its usage as a fuel. The accepted range of water content in bio-oil is between 25-26 wt\% [87]. Table 5 deduce that the water content in the bio-oil extracted from empty fruit bunch (EFB), sugarcane bagasse, banana stem and softwood are in acceptable range. On the other side bio-oil of rice husk, wheat straw and hardwood shows high amount of water content and may not be suitable to be used directly without further improvements. Density of bio-oil from all biomass was found to be in between of 900 to $1,548 \mathrm{~kg} / \mathrm{m}^{3}$. These values are considered higher compare to the density of crude oil which around 860 $\mathrm{kg} / \mathrm{m}^{3}$ [88]. High density values means that the bio-oil has high amount of oxygen instead of polycyclic aromatic which presence mostly in hydrocarbon oil. Bio-oil from woody biomass usually has low $\mathrm{pH}$ value which is around 3.7 only because it contains some organic acid such as acetic and formic acid [89]. Table 5 deduces that the $\mathrm{pH}$ of bio-oil from all the biomass is between 1.5-3.85 which is in the range of proposed literature. The proposed viscosity for bio-oil derived from biomass is 40-100 cP. Table 5 shows that the viscosity of bio-oil varied over a wide range depending on the type of biomass and also experimental conditions. The heating value of all the bio-oil is very low compared to heating value of heavy fuel oil which is at $40 \mathrm{MJ} / \mathrm{kg}$ [90]. This may due to the high amount of water content which results in the decreasing of energy in the oil.

\subsection{Bio-oil Utilizations in Industry}

Bio-oil is obtained from the burning of dried biomass in a reactor in the absence of oxygen at temperature about $500^{\circ} \mathrm{C}$ with sub-

Table 5. Comparison of Properties between Bio-oils from Different Feedstocks

\begin{tabular}{|c|c|c|c|c|c|c|c|c|c|c|c|}
\hline Properties & $\begin{array}{c}\text { EFB } \\
{[91-93]}\end{array}$ & $\begin{array}{c}\text { Sugarcane } \\
\text { bagasse } \\
{[46]}\end{array}$ & $\begin{array}{c}\text { Rice husk } \\
\text { [94] }\end{array}$ & $\begin{array}{c}\text { Coconut } \\
\text { shell } \\
{[31,59]}\end{array}$ & $\begin{array}{c}\text { Wood } \\
\text { sawdust } \\
{[95]}\end{array}$ & $\begin{array}{c}\text { Corn } \\
\text { stover } \\
{[95]}\end{array}$ & $\begin{array}{c}\text { Wheat } \\
\text { straw } \\
{[96]}\end{array}$ & $\begin{array}{c}\text { Municipal solid } \\
\text { waste } \\
\text { (paper waste) } \\
\text { [38] }\end{array}$ & $\begin{array}{c}\text { Banana } \\
\text { stem } \\
{[81]}\end{array}$ & $\begin{array}{c}\text { Softwood } \\
\text { [97] }\end{array}$ & $\begin{array}{c}\text { Hardwood } \\
{[98]}\end{array}$ \\
\hline $\begin{array}{l}\text { Kinematic } \\
\text { viscosity (cSt) }\end{array}$ & 38.4 & 21.50 & $4.861-16.277$ & 36 & $\begin{array}{c}14 \\
\left(\mathrm{cP}, \text { at } 40^{\circ} \mathrm{C}\right)\end{array}$ & $\begin{array}{c}13 \\
\left(\mathrm{cP}, \text { at } 40^{\circ} \mathrm{C}\right)\end{array}$ & 23.5 & 2.00 & - & 62 & 32.63 \\
\hline $\begin{array}{l}\text { Density } \\
\left(\mathrm{kg} \mathrm{m}^{-3}\right)\end{array}$ & $900-1,548$ & 1,150 & $1,138-1,170$ & 1,090 & 1,060 & 1,020 & - & 1,205 & 1,200 & 1,188 & 1,232 \\
\hline $\mathrm{pH}$ & 2.8 & 3.85 & $2.85-3.2$ & $3.15-3.28$ & 2.07 & 2.64 & 2.4 & 1.5 & $3.18 \pm 0.02$ & 3.00 & - \\
\hline $\begin{array}{l}\mathrm{HHV} \\
(\mathrm{MJ} \mathrm{kg})\end{array}$ & 36.06 & 23.50 & $14.285-21.742$ & 38.6 & 20.38 & 20.39 & 24.2 & 13.10 & 7.97 & 27.9 & 14.34 \\
\hline Water content (\%) & 7.90 & 11.60 & $26.18-41.32$ & - & - & - & 26.7 & - & $20.0 \pm 0.1$ & 13.0 & 32 \\
\hline \multicolumn{12}{|l|}{$\begin{array}{l}\text { Elemental analysis } \\
(\%)\end{array}$} \\
\hline $\mathrm{C}$ & 69.35 & 52.62 & $37.86 \pm 0.21$ & 75.4 & 24.86 & 13.00 & 50.78 & 40.80 & 9.70 & 62.6 & 54.59 \\
\hline $\mathrm{H}$ & 9.61 & 7.40 & $5.24 \pm 0.01$ & 11.7 & 7.17 & 8.08 & 3.20 & 6.29 & 11.21 & 7.0 & 6.74 \\
\hline 0 & 20.02 & 39.10 & $35.32 \pm 2.15$ & 10.5 & 67.61 & 78.39 & 44.42 & 52.91 & 50.42 & 29.0 & 38.57 \\
\hline $\mathrm{N}$ & 0.74 & 0.75 & $0.68 \pm 0.06$ & 2.4 & 0.35 & 0.53 & 1.37 & - & 28.67 & 1.1 & 0.10 \\
\hline S & - & $<0.07$ & - & - & - & - & - & - & - & $<0.1$ & - \\
\hline
\end{tabular}


Table 6. Application of Bio-oil in Industry

\begin{tabular}{ll}
\hline Products & $\begin{array}{l}\text { Function } \\
\text { Asphalt binder }\end{array}$ \\
\hline $\begin{array}{l}\text { Asphalt or bitumen used in the road construction is produced from refining of crude oil. Bio-oil } \\
\text { is mixed with the base binder to produce a bio modified binder. }\end{array}$ \\
\hline Adhesive & $\begin{array}{l}\text { Adhesive is known as glue. Phenol component in adhesive is extacted from crude oil. Bio-oil } \\
\text { which comprises of phenolic compound is used to replace parts of the adhesive. }\end{array}$ \\
\hline Resins & $\begin{array}{l}\text { Resin originated from plant or synthetic can be used in the making of polymer. Bio-oil was } \\
\text { used as a source of phenolic compounds in the production of a bio-based polymeric network. }\end{array}$ \\
\hline Food flovoring & Vanillin which is an artificial vanilla flavour is made from lignin extracted from bio-oil. \\
\hline Agrichemicals & $\begin{array}{l}\text { Bio-oil have many organic compound that can be used in the making of bio-based fertilizers } \\
\text { and pestisides. }\end{array}$ \\
\hline
\end{tabular}

sequent cooling. The physical appearance of bio-oil is dark-brown liquid with a strong odor [99]. Bio-oil produced from fast pyrolysis and thermal liquefaction can be utilized in many sectors. It can be used as heat and power generation, liquid fuels, and raw chemical products. Chemicals extracted from bio-oil are mostly used in construction, food flavorings, resins, adhesives, and agrichemicals. Table 6 describes the application of bio-oil in industry and its function.

\section{Conclusions}

It is crucial to select the best process to transform biomass into bio-oil which can be a viable alternative to fossil fuels. Thermo-chemical liquefaction and pyrolysis method is the best process to achieve this goal. From the literature it can be concluded that pyrolysis method has gained a huge amount of interest compare to liquefaction method as it produces large quantity of bio-oil and the quality is much better. Fast pyrolysis method with fluidized bed and fixed bed reactor has been used the most by researchers as it produce higher yield of bio-oil. This review article conclude that high yield of bio-oil was obtained from palm EFB, sugarcane bagasse, rice husk, coconut shell, wood sawdust, corn stover, wheat straw, municipal solid waste, banana stem, softwood and hardwood is at atmospheric pressure and temperature range between $400^{\circ} \mathrm{C}$ to $615^{\circ} \mathrm{C}$. Hydrothermal liquefaction, microwave pyrolysis and slow pyrolysis method which is another way to obtain bio-oil, is also a process of interest. Low quality of bio-oil properties such as high-water content, low $\mathrm{pH}$ and heat value limits its utilization. Hence further improvisation of bio-oil is required in order to produce a high-grade of liquid fuel.

\section{Acknowledgments}

The authors would like to express deep gratitude to Dr. Farzana Kabir Ahmad from University Utara Malaysia (UUM) who constantly gives encouragement throughout the preparation of this review article.

\section{References}

1. Demirbas A. Fuels from biomass. In: Biorefineries. Green energy and technology book series. London: Springer; 2010. p. 33-73.

2. Energy, carbon saving and sustainability [Internet]. [cited 26 February 2018]. Available from: http://clients.junction-18.com/ beep/Biomass/\#/1.

3. National Statistics. Agriculture in the United Kingdom [Internet]. [cited 15 March 2018]. Available from: https:// assets.publishing.service.gov.uk/government/uploads/system/ uploads/attachment_data/file/208436/auk-2012-25jun13.pdf.

4. Yang J, Wang X, Ma H, Bai J, Jiang Y, Yu H. Potential usage, vertical value chain and challenge of biomass resource: Evidence from China's crop residues. Appl. Energ. 2014; 114:717-723.

5. Report on the availability of biomass sources in Spain: Vineyards and olive groves [Internet]. [cited 7 May 2018]. Available from: https://www.researchgate.net/publication/ 321760198_Report_on_the_availability_of_Biomass_ Sources in Spain_vineyards_and olive_groves.

6. Tan Z, Chen K, Liu P. Possibilities and challenges of China's forestry biomass resource utilization. Renew. Sust. Energ. Rev. 2015;41:368-378.

7. Vezzoli C, Ceschin F, Osanjo L, et al. Energy and sustainable development. In: Designing sustainable energy for all. Springer; 2018. p. 3-22.

8. Aalto M, Korpinen O-J, Loukola J, Ranta T. Achieving a smooth flow of fuel deliveries by truck to an urban biomass power plant in Helsinki, Finland-An agent-based simulation approach. Int. J. Forest Eng. 2018;29:21-30.

9. Lora ES, Andrade RV. Biomass as energy source in Brazil. Renew. Sust. Energ. Rev. 2009;13:777-788.

10. Ericsson K, Werner S. The introduction and expansion of biomass use in Swedish district heating systems. Biomass Bioenerg. 2016;94:57-65.

11. Shafie SM, Mahlia TMI, Masjuki HH, Ahmad-Yazid A. A review on electricity generation based on biomass residue in Malaysia. Renew. Sust. Energ. Rev. 2012;16:5879-5889.

12. Mekhilef S, Saidur R, Safari A, Mustaffa WESB. Biomass energy in Malaysia: Current state and prospects. Renew. Sust. Energ. 
Rev. 2011;15:3360-3370.

13. Assanee N, Boonwan C. State of the art of biomass gasification power plants in Thailand. Energ. Procedia 2011;9:299-305.

14. Darabant A, Haruthaithanasan M, Atkla W, Phudphong T, Thanavat E, Haruthaithanasan K. Bamboo biomass yield and feedstock characteristics of energy plantations in Thailand. Energ. Procedia 2014;59:134-141.

15. Mirza UK, Ahmad N, Majeed T. An overview of biomass energy utilization in Pakistan. Renew. Sust. Energ. Rev. 2008;12:1988-1996.

16. Singh NB, Kumar A, Rai S. Potential production of bioenergy from biomass in an Indian perspective. Renew. Sust. Energ. Rev. 2014;39:65-78.

17. Cardoen D, Joshi P, Diels L, Sarma PM, Pant D. Agriculture biomass in India: Part 2. Post-harvest losses, cost and environmental impacts. Resour. Conserv. Recycl. 2015;101:143-153.

18. Williams CL, Westover TL, Emerson RM, Tumuluru JS, Li C. Sources of biomass feedstock variability and the potential impact on biofuels production. BioEnerg. Res. 2015;9:1-14.

19. Saini JK, Saini R, Tewari L. Lignocellulosic agriculture wastes as biomass feedstocks for second-generation bioethanol production: Concepts and recent developments. 3 Biotech 2014;5:337-353.

20. Iqbal HMN, Ahmed I, Zia MA, Irfan M. Purification and characterization of the kinetic parameters of cellulase produced from wheat straw by Trichoderma viride under SSF and its detergent compatibility. Adv. Biosci. Biotechnol. 2011;2:149-156.

21. Welker C, Balasubramanian V, Petti C, Rai K, DeBolt S, Mendu V. Engineering plant biomass lignin content and composition for biofuels and bioproducts. Energies 2015;8:7654-7676.

22. Isahak WNRW, Hisham MWM, Yarmo MA, Yun Hin T. A review on bio-oil production from biomass by using pyrolysis method. Renew. Sust. Energ. Rev. 2012;16:5910-5923.

23. Das P, Ganesh A, Wangikar P. Influence of pretreatment for deashing of sugarcane bagasse on pyrolysis products. Biomass Bioenerg. 2004;27:445-457.

24. Raveendran K, Ganesh A, Khilar KC. Influence of mineral matter on biomass pyrolysis characteristics. Fuel 1995;74:1812-1822.

25. Bledzki AK, Mamun AA, Volk J. Barley husk and coconut shell reinforced polypropylene composites: The effect of fibre physical, chemical and surface properties. Compos. Sci. Technol. 2010;70:840-846.

26. Weil J, Brewer M, Hendrickson R, Sarikaya A, Ladisch MR. Continuous $\mathrm{pH}$ monitoring during pretreatment of yellow poplar wood sawdust by pressure cooking in water. Appl. Biochem. Biotechnol. 1998;70-72:99-111.

27. Šćiban M, Radetić B, Kevrešan Ž, Klašnja M. Adsorption of heavy metals from electroplating wastewater by wood sawdust. Bioresour. Technol. 2007;98:402-409.

28. Nishimura H, Tan L, Sun Z-Y, Tang Y-Q, Kida K, Morimura S. Efficient production of ethanol from waste paper and the biochemical methane potential of stillage eluted from ethanol fermentation. Waste Manage. 2016;48:644-651.

29. Abdul Khalil HPS, Siti Alwani M, Mohd Omar AK. Chemical composition, anatomy, lignin distribution, and cell wall structure of Malaysian plant waste fibers. BioResources 2006;1: 220-232.

30. Kim SW, Koo BS, Ryu JW, et al. Bio-oil from the pyrolysis of palm and Jatropha wastes in a fluidized bed. Fuel Process. Technol. 2013;108:118-124.

31. Tsai WT, Lee MK, Chang YM. Fast pyrolysis of rice straw, sugarcane bagasse and coconut shell in an induction-heating reactor. J. Anal. Appl. Pyrol. 2006;76:230-237.

32. Tsai W, Lee M, Chang Y. Fast pyrolysis of rice husk: Product yields and compositions. Bioresour. Technol. 2007;98:22-28.

33. Worasuwannarak N, Sonobe T, Tanthapanichakoon W. Pyrolysis behaviors of rice straw, rice husk, and corncob by TG-MS technique. J. Anal. Appl. Pyrol. 2007;78:265-271.

34. Altafini CR, Wander PR, Barreto RM. Prediction of the working parameters of a wood waste gasifier through an equilibrium model. Energ. Convers. Manage. 2003;44:2763-2777.

35. Yu F, Deng S, Chen P, et al. Physical and chemical properties of bio-oils from microwave pyrolysis of corn stover. Appl. Biochem. Biotechnol. 2007;137-140:957-970.

36. Mullen CA, Boateng AA, Goldberg NM, Lima IM, Laird DA, Hicks KB. Bio-oil and bio-char production from corn cobs and stover by fast pyrolysis. Biomass Bioenerg. 2010;34:67-74.

37. Bridgeman TG, Jones JM, Shield I, Williams PT. Torrefaction of reed canary grass, wheat straw and willow to enhance solid fuel qualities and combustion properties. Fuel 2008;87:844-856.

38. Nurul Islam M, Nurul Islam M, Rafiqul Alam Beg M, Rofiqul Islam M. Pyrolytic oil from fixed bed pyrolysis of municipal solid waste and its characterization. Renew. Energ. 2005;30: 413-420.

39. Minowa T, Kondo T, Sudirjo ST. Thermochemical liquefaction of Indonesian biomass residues. Biomass Bioenerg. 1998;14: 517-524.

40. Sellin N, Oliveiraa BG, Marangonia C, Souzaa O, Oliveira APN, Oliveira TMN. Use of banana culture waste to produce briquettes. Italian Assoc. Chem. Eng. 2013;37:439-444.

41. Demirbaş A. Calculation of higher heating values of biomass fuels. Fuel 1997;76:431-434.

42. Module 2: Heterogeneous catalysis. Lecture 18: Catalysts test and Reactors types [Internet]. [cited 11 February 2019]. Available from: https://nptel.ac.in/courses/103103026/module2/lec18/1.html.

43. Vecino Mantilla S, Gauthier-Maradei P, Álvarez Gil P, Tarazona Cárdenas S. Comparative study of bio-oil production from sugarcane bagasse and palm empty fruit bunch: Yield optimization and bio-oil characterization. J. Anal. Appl. Pyrol. 2014;108: 284-294.

44. Sembiring KC, Rinaldi N, Simanungkalit SP. Bio-oil from fast pyrolysis of empty fruit bunch at various temperature. Energ. Procedia 2015;65:162-169.

45. Chan YH, Yusup S, Quitain AT, Uemura Y, Sasaki M. Bio-oil production from oil palm biomass via subcritical and supercritical hydrothermal liquefaction. J. Supercrit. Fluid. 2014;95:407-412.

46. Montoya JI, Valdés C, Chejne F, et al. Bio-oil production from Colombian bagasse by fast pyrolysis in a fluidized bed: An experimental study. J. Anal. Appl. Pyrol. 2015;112:379-387.

47. Phan BMQ, Duong LT, Nguyen VD, et al. Evaluation of the production potential of bio-oil from Vietnamese biomass resources by fast pyrolysis. Biomass Bioenerg. 2014;62:74-81. 48. Mesa-Pérez JM, Rocha JD, Barbosa-Cortez LA, Penedo-Medina 
M, Luengo CA, Cascarosa E. Fast oxidative pyrolysis of sugar cane straw in a fluidized bed reactor. Appl. Therm. Eng. 2013;56:167-175.

49. Varma AK, Mondal P. Pyrolysis of sugarcane bagasse in semi batch reactor: Effects of process parameters on product yields and characterization of products. Ind. Crops Prod. 2017;95: 704-717.

50. Henkel C, Muley PD, Abdollahi KK, Marculescu C, Boldor D. Pyrolysis of energy cane bagasse and invasive Chinese tallow tree (Triadica sebifera L.) biomass in an inductively heated reactor. Energ. Convers. Manage. 2016;109:175-183.

51. Liu Y, Yuan X, Huang H, Wang X, Wang H, Zeng G. Thermochemical liquefaction of rice husk for bio-oil production in mixed solvent (ethanol-water). Fuel Process. Technol. 2013;112:93-99.

52. Alvarez J, Lopez G, Amutio M, Bilbao J, Olazar M. Bio-oil production from rice husk fast pyrolysis in a conical spouted bed reactor. Fuel 2014;128:162-169.

53. Zhou L, Yang H, Wu H, Wang M, Cheng D. Catalytic pyrolysis of rice husk by mixing with zinc oxide: Characterization of bio-oil and its rheological behavior. Fuel Process. Technol. 2013;106:385-391.

54. Naqvi SR, Uemura Y, Yusup SB. Catalytic pyrolysis of paddy husk in a drop type pyrolyzer for bio-oil production: The role of temperature and catalyst. J. Anal. Appl. Pyrol. 2014;106:57-62.

55. Abu Bakar MS, Titiloye JO. Catalytic pyrolysis of rice husk for bio-oil production. J. Anal. Appl. Pyrol. 2013;103:362-368.

56. Cai W, Liu R. Performance of a commercial-scale biomass fast pyrolysis plant for bio-oil production. Fuel 2016;182:677-686.

57. Hsu C-P, Huang A-N, Kuo H-P. Analysis of the rice husk pyrolysis products from a fluidized bed reactor. Procedia Eng. 2015;102:1183-1186.

58. Zhao N, Li B-X. The effect of sodium chloride on the pyrolysis of rice husk. Appl. Energ. 2016;178:346-352.

59. Rout T, Pradhan D, Singh RK, Kumari N. Exhaustive study of products obtained from coconut shell pyrolysis. J. Environ. Chem. Eng. 2016;4:3696-3705.

60. Gao Y, Yang Y, Qin Z, Sun Y. Factors affecting the yield of bio-oil from the pyrolysis of coconut shell. SpringerPlus 2016;5:333.

61. Siengchum T, Isenberg M, Chuang SSC. Fast pyrolysis of coconut biomass - An FTIR study. Fuel 2013;105:559-565.

62. Makibar J, Fernandez-Akarregi AR, Amutio M, Lopez G, Olazar M. Performance of a conical spouted bed pilot plant for bio-oil production by poplar flash pyrolysis. Fuel Process. Technol. 2015;137:283-289.

63. Özbay G. Catalytic pyrolysis of pine wood sawdust to produce bio-oil: Effect of temperature and catalyst additives. J. Wood Chem. Technol. 2015;35:302-313.

64. Nazari L, Yuan Z, Souzanchi S, Ray MB, Xu C (Charles). Hydrothermal liquefaction of woody biomass in hot-compressed water: Catalyst screening and comprehensive characterization of bio-crude oils. Fuel 2015;162:74-83.

65. Yorgun S, Yıldız D. Slow pyrolysis of paulownia wood: Effects of pyrolysis parameters on product yields and bio-oil characterization. J. Anal. Appl. Pyrol. 2015;114:68-78.

66. Salehi E, Abedi J, Harding TG, Seyedeyn-Azad F. Bio-oil from sawdust: Design, operation, and performance of a bench-scale fluidized-bed pyrolysis plant. Energ. Fuel. 2013;27:3332-3340.

67. Özbay G. Pyrolysis of firwood (Abies bornmülleriana Mattf.) sawdust: Characterization of bio-oil and bio-char. Drvna Ind. 2015;66:105-114.

68. Moralı U, Yavuzel N, Şensöz S. Pyrolysis of hornbeam (Carpinus betulus L.) sawdust: Characterization of bio-oil and bio-char. Bioresour. Technol. 2016;221:682-685.

69. Liu S, Xie Q, Zhang B, et al. Fast microwave-assisted catalytic co-pyrolysis of corn stover and scum for bio-oil production with $\mathrm{CaO}$ and HZSM-5 as the catalyst. Bioresour. Technol. 2016;204:164-170.

70. Chen T, Liu R, Scott NR. Characterization of energy carriers obtained from the pyrolysis of white ash, switchgrass and corn stover - Biochar, syngas and bio-oil. Fuel Process. Technol. 2016;142:124-134.

71. Mante OD, Agblevor FA. Catalytic pyrolysis for the production of refinery-ready biocrude oils from six different biomass sources. Green Chem. 2014;16:3364-3377.

72. Ravikumar C, Senthil Kumar P, Subhashni SK, Tejaswini PV, Varshini V. Microwave assisted fast pyrolysis of corn cob, corn stover, saw dust and rice straw: Experimental investigation on bio-oil yield and high heating values. Sust. Mater. Technol. 2017;11:19-27.

73. Liu S, Zhang Y, Fan L, et al. Bio-oil production from sequential two-step catalytic fast microwave-assisted biomass pyrolysis. Fuel 2017;196:261-268.

74. Biswas B, Pandey N, Bisht Y, Singh R, Kumar J, Bhaskar T. Pyrolysis of agricultural biomass residues: Comparative study of corn cob, wheat straw, rice straw and rice husk. Bioresour. Technol. 2017;237:57-63.

75. Oudenhoven SRG, Westerhof RJM, Kersten SRA. Fast pyrolysis of organic acid leached wood, straw, hay and bagasse: Improved oil and sugar yields. J. Anal. Appl. Pyrol. 2015;116:253-262.

76. Patil PT, Armbruster U, Martin A. Hydrothermal liquefaction of wheat straw in hot compressed water and subcritical water-alcohol mixtures. J. Supercrit. Fluid. 2014;93:121-129.

77. Tomás-Pejó E, Fermoso J, Herrador E, et al. Valorization of steam-exploded wheat straw through a biorefinery approach: Bioethanol and bio-oil co-production. Fuel 2017;199:403-412.

78. Suriapparao DV, Vinu R. Bio-oil production via catalytic microwave pyrolysis of model municipal solid waste component mixtures. RSC Adv. 2015;5:57619-57631.

79. Sellin N, Krohl DR, Marangoni C, Souza O. Oxidative fast pyrolysis of banana leaves in fluidized bed reactor. Renew. Energ. 2016;96:56-64.

80. Abdullah N, Sulaiman F, Taib RM, Miskam MA. Pyrolytic oil of banana (Musa spp.) pseudo-stem via fast process. In: AIP Conference Proceeding; 24 April 2015.

81. Torri IDV, Paasikallio V, Faccini CS, et al. Bio-oil production of softwood and hardwood forest industry residues through fast and intermediate pyrolysis and its chromatographic characterization. Bioresour. Technol. 2016;200:680-690.

82. Charon N, Ponthus J, Espinat D, et al. Multi-technique characterization of fast pyrolysis oils. J. Anal. Appl. Pyrol. 2015;116:18-26.

83. Kim KH, Kim T-S, Lee S-M, et al. Comparison of physicochemical features of biooils and biochars produced from 
various woody biomasses by fast pyrolysis. Renew. Energ. 2013;50:188-195.

84. Papari S, Hawboldt K, Helleur R. Pyrolysis: A theoretical and experimental study on the conversion of softwood sawmill residues to biooil. Ind. Eng. Chem. Res. 2015;54:605-611.

85. Mazlan MAF, Uemura Y, Osman NB, Yusup S. Fast pyrolysis of hardwood residues using a fixed bed drop-type pyrolyzer. Energ. Convers. Manage. 2015;98:208-214.

86. Ahiekpor JC, Kuye AO, Achaw OW. Optimization of the pyrolysis of hardwood sawdust in a fixed bed reactor using surface response methodology. Lignocellulose 2017;6:98-108.

87. Oasmaa A, Meier D. Characterisation, analysis, norms and standards. In: Bridgwater AV, ed. Fast pyrolysis of biomass: A handbook. United Kingdom; 2005. p. 19-60.

88. Mortensen PM, Grunwaldt J-D, Jensen PA, Knudsen KG, Jensen $\mathrm{AD}$. A review of catalytic upgrading of bio-oil to engine fuels. Appl. Catal. A. Gen. 2011;407:1-19.

89. Oasmaa A, Meier D. Analysis, characterization and test methods of fast pyrolysis liquids. In: Bridgwater AV, ed. Fast pyrolysis of biomass: A handbook. Newbury; 2002. p. 23-35.

90. Mohan D, Pittman CU, Steele PH. Pyrolysis of wood/biomass for bio-oil: A critical review. Energ. Fuel. 2006;20:848-889.

91. Abdullah N, Gerhauser H, Sulaiman F. Fast pyrolysis of empty fruit bunches. Fuel 2010;89:2166-2169.

92. Solikhah MD, Pratiwi FT, Heryana Y, et al. Characterization of bio-oil from fast pyrolysis of palm frond and empty fruit bunch. In: IOP conference series: Materials science and engineering. Volume 349. IOP Publishing; 2018.

93. Chang SH. An overview of empty fruit bunch from oil palm as feedstock for bio-oil production. Biomass Bioenerg. 2014;62:174-181.

94. Cai W, Liu R, He Y, Chai M, Cai J. Bio-oil production from fast pyrolysis of rice husk in a commercial-scale plant with a downdraft circulating fluidized bed reactor. Fuel Process.
Technol. 2018;171:308-317.

95. Borges FC, Du Z, Xie Q, et al. Fast microwave assisted pyrolysis of biomass using microwave absorbent. Bioresour. Technol. 2014;156:267-274.

96. Mullen CA, Boateng AA, Hicks KB, Goldberg NM, Moreau RA. Analysis and comparison of bio-oil produced by fast pyrolysis from three barley biomass/byproduct streams. Energ. Fuel. 2010;24:699-706.

97. Ba T, Chaala A, Garcia-Perez M, Rodrigue D, Roy C. Colloidal properties of bio-oils obtained by vacuum pyrolysis of softwood bark. Characterization of water-soluble and water-insoluble fractions. Energ. Fuel. 2004;18:704-712.

98. Tzanetakis T, Ashgriz N, James DF, Thomson MJ. Liquid fuel properties of a hardwood-derived bio-oil fraction. Energ. Fuel. 2008;22:2725-2733.

99. Wikipedia. Pyrolysis oil [Internet]. [cited 5 September 2018]. Available from: https://en.wikipedia.org/w/index.php?title= Pyrolysis_oil\&oldid $=845786946$.

100. Abdul Raman NA, Hainin MR, Abdul Hassan N, Ani FN. A review on the application of bio-oil as an additive for asphalt. J. Teknol. 2015;72:105-110.

101. Mathias J-D, Grédiac M, Michaud P. Bio-based adhesives. In: Biopolymers and biotech admixtures for eco-efficient construction materials. Cambridge: Woodhead Publishing; 2016. p. 369-385.

102. Sibaja B, Adhikari S, Celikbag Y, Via B, Auad ML. Fast pyrolysis bio-oil as precursor of thermosetting epoxy resins. Polym. Eng. Sci. 2018;58:1296-1307.

103. Fache M, Darroman E, Besse V, Auvergne R, Caillol S, Boutevin B. Vanillin, a promising biobased building-block for monomer synthesis. Green Chem. 2014;16:1987-1998.

104. Maheshwari DK. Composting for sustainable agriculture. Switzerland: Springer International Publishing; 2014. 